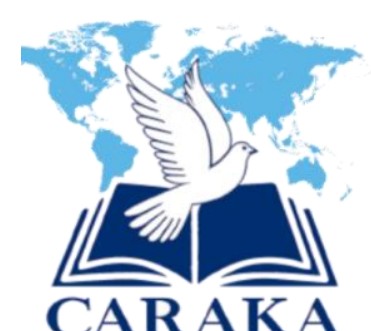

\title{
Sinergi Pelayan dan Jemaat Tuhan Menurut 1 Korintus 3:4-9
}

\author{
Desti Ratna Sari Halawa \\ Sekolah Tinggi Teologi Soteria Purwokerto \\ halawadestiratnasari@gmail.com
}

\begin{abstract}
This paper examines the meaning of synergy in the ministry and life of believers according to 1 Corinthians 3: 4-9. Servants of God tend to leave the place of service because they are at odds with God or others. Among the Corinthians in the early church, there was strife among the members of the body of Christ. To deal with divisions, Paul talks about becoming partners with God (synergy). In the Orthodox church this concept emphasizes how to achieve salvation but this concept is not emphasized in the world of ministry. Whereas in Protestant literature this concept is rarely even perhaps foreign to be discussed as something important, so that it is reflected in ministries within the church and outside the church which often cause divisions. The results show that only through synergy with God can humans synergize with one another (one with God and one with others remains strong). Synergize is to be partners with Allah who continue to exercise their free will according to God's will so that they are not easily tempted by the evil of sin. Remembering God dynamically produces union with God and gives the best service to others as Christ served. Of course, only synergy makes humans avoid fellowship and enmity between others.
\end{abstract}

Keywords: Congregational unity; Spiritual growth; Fellow servants of God; Synergy of God

\begin{abstract}
Abstrak
Tulisan ini meneliti makna sinergi dalam pelayanan dan kehidupan orang percaya menurut 1 Korintus 3:4-9. Pelayan Tuhan cenderung meninggalkan tempat pelayanan karena berselisih dengan Allah atau sesama. Di antara jemaat Korintus di masa gereja mula-mula perselisihan di antara anggota tubuh Kristus sudah terjadi. Untuk menghadapi perpecahan, Paulus berbicara bagaimana menjadi kawan sekerja Allah (sinergi). Dalam gereja Ortodoks konsep ini menekankan bagaimana mencapai keselamatan akan tetapi konsep ini tidak ditekankan dalam dunia pelayanan. Sedangkan dalam literatur Protestan konsep ini jarang bahkan mungkin asing dibahas sebagai sesuatu yang penting, sehingga tercermin dalam pelayanan-pelayanan dalam gereja maupun di luar gereja yang sering menimbulkan perpecahan. Hasil penelitian menunjukkan bahwa hanya melalui sinergi dengan Allah manusia bisa bersinergi dengan sesamanya (menyatu dengan Allah dan persatuan dengan sesama tetap kokoh). Bersinergi adalah menjadi kawan sekerja Allah yang terus melatih kehendak bebasnya sesuai dengan kehendak Allah sehingga tidak mudah tergoda oleh kejahatan dosa. Mengingat Allah secara dinamis menghasilkan persatuan dengan Allah dan memberi pelayanan terbaik kepada sesama seperti Kristus melayani. Tentunya, hanya sinergilah yang membuat manusia terhindar dari persekutuan serta permusuhan di antara sesama.
\end{abstract}

Kata kunci: Persatuan jemaat; Pertumbuhan rohani; Rekan pelayan Tuhan; Sinergi Allah 


\section{PENDAHULUAN}

Setiap gereja pasti tidak akan pernah terlepas dari dunia pelayanan. Ada berbagai bentuk pelayanan dalam gereja seperti sebagai pendeta, pengurus gereja, majelis, guru sekolah minggu, tim musik, dan lain sebagainya. Peranan para pelayan Tuhan memberikan pengaruh besar bagi warga gereja maupun dilingkungan mereka berada. Dalam mengemban pelayanan, prosesnya tidak selalu berjalan mulus, tetapi ada saja serangan-serangan dari si jahat atau iblis yang hendak menggagalkan pelayan gereja. Mungkin saja berselisih dengan sesama pelayan Tuhan, pelayan Tuhan berselisih dengan jemaat atau jemaat Tuhan berselisih dengan sesama jemaat. Daniel N. Tanusaputra mengatakan, "Kebanyakan orang Kristen mengalami kehidupan rohani yang tanpa penghayatan sehingga stagnan, tidak terjadi proses pertumbuhan dan kematangan"1. Hal ini menunjukkan pengikut Kristus ada kemungkinan jatuh berdosa. Demikian juga dalam gereja mula-mula setelah kebangkitan Yesus Kristus, para murid mengabarkan injil di mana-mana, salah satunya di Kota Korintus. Namun, di antara jemaat terjadi perpecahan dan perselisihan. Ada yang mengatakan saya dari Paulus dan yang lain mengatakan saya dari Apolos. Masalah tentang perpecahan dan perselisihan terus ada sampai sekarang (era digital) dalam kehidupan orang percaya maupun para pelayan Tuhan.

Berangkat dari masalah diatas, penulis melihat pentingnya meninjau kembali surat Paulus kepada Korintus, Hal ini dikarenakan oleh Firman yang tertulis bukan hanya ditujukan kepada jemaat Korintus tetapi ditujukan kepada masing-masing pribadi orang Kristen yang adalah anggota tubuh Kristus. ${ }^{2}$ Salah satu hal mengejutkan ketika Paulus menghadapi perpecahan jemaat, rasul ini berbicara tentang bagaimana menjadi kawan sekerja Allah (sinergi). Dalam gereja Ortodoks konsep ini sangat ditekankan terutama bagaimana mencapai keselamatan, ${ }^{3}$ akan tetapi konsep ini tidak ditekankan dalam dunia pelayanan. Sedangkan gereja-gereja Protestan kurang memperhatikan sinergi dalam menjalankan pelayananpelayanan dalam gereja maupun di luar gereja sehingga yang terjadi adalah perpecahan gereja terjadi dengan sangat pesat. Penulis berargumen bahwa hanya melalui sinergi dengan Allah, manusia bisa bersinergi dengan sesamanya. Selain itu, dengan bersinergi dengan Allah, hati manusia diisi oleh Allah, sehingga hatinya tidak mudah melakukan dosa.

\footnotetext{
${ }^{1}$ Daniel N. Tanusaputra, “ Kerohanian dan Pelayanan Seorang Hamba Tuhan,” Veritas: Jurnal Teologi dan Pelayanan 14, no. 2 (Oktober 2013): 255.

${ }^{2}$ Hendi menyatakan setuju dengan tulisan Kallistos Ware, bahwa setelah menemukan pengetahuan dalam Alkitab, langkah selanjutnya adalah membaca Alkitab dengan prinsip menekankan sifat personal. Mengapa? Firman harus dimatangkan dalam hati supaya dalam hati menimbulkan keinginan yang baik atau keinginan Roh Kudus, lihat Hendi, "Bagaimana Membaca Alkitab," Sekolah Tinggi Teologi Soteria Purwokerto, 13 November 2017, https://www.sttsoteria.ac.id/2017/11/tiga-level-pembacaan-alkitab.html (diakses 25 November 2020).

${ }^{3}$ Hanya melalui sinergi atau kerjasama antara Allah dan manusia seseorang mencapai keselamatan. Keselamatan adalah penyatuan dengan energi Allah dan bukan esensi-Nya. Lihat Gregory Palamas, The Philokalia, jilid 4 (London: Faber and Faber 1995), 291.
} 
Artikel ini akan menjelaskan bahwa fondasi dari pelayanan jemaat adalah bersinergi dengan Allah, kemudian menjelaskan bagaimana cara bersinergi dengan Allah dan sesama serta hasil dari bersinergi yang dimaksud berdasarkan 1 Korintus 3:4-9. Tujuan yang ingin dicapai dari hasil penelitian ini adalah: Pertama, untuk menemukan konsep sinergi dalam pelayanan berkenaan dengan penafsiran teks 1 Korintus 3:4-9. Kedua, penelitian ini akan memberikan sumbangsih praksis bagi orang percaya dalam menaklukkan keinginan daging supaya tidak terjadi perpecahan melalui sinergi dengan Allah.

\section{METODE PENELITIAN}

Metode yang digunakan adalah metode tafsir eksegesis yang artinya membaca suatu teks Alkitab dari bahasa asli yaitu bahasa Yunani. Kemudian, penulis membawa keluar poinpoin yang ditemukan. Menemukan poin berguna untuk menemukan pesan Firman Allah. Tahapan selanjutnya dalam penelitian ini adalah menemukan hasil makna rohani atau dari 1 Korintus 3:4-9 dan membahasnya dengan membuat konsep untuk diajarkan kepada orang lain. Ide utamanya adalah "sinergi" sedangkan ide-ide pendukungnya adalah: (1) Menjadi kawan sekerja Allah. (2) Para pelayan dan jemaat saling bekerjasama dengan Allah. (3) Hasil dari bersinergi adalah adanya persatuan dan mencapai pada keadaan manusia rohani. 3 hal diatas akan menjadi fokus pembahasan dengan memperhatikan ayat-ayat dalam Alkitab yang bersinggungan, tulisan Bapa-Bapa Gereja, buku-buku tafsiran, serta artikel jurnal lainnya. Dengan demikian penulis menemukan konsep sinergi, dan implikasi dalam pelayanan.

\section{HASIL DAN PEMBAHASAN}

Sinergi dengan Allah adalah cara orang percaya mencapai persatuan akhir (theosis ${ }^{4}$ ) dengan Allah serta menolong sifat manusia lama semakin diperbaharui menjadi manusia baru atau rohani. Menjadi manusia baru adalah menjadi dewasa rohani. Orang percaya membutuhkan yang namanya kedewasaan rohani, karena kedewasaan rohani suatu kondisi yang harus dijalani oleh orang percaya. ${ }^{5}$ Sinergi dengan Allah menolong para pelayan Tuhan untuk mementingkan visi Tuhan dan bukan visi pribadi dalam pelayanan.

\section{Bersinergi Adalah Menjadi Kawan Sekerja Allah}

Berdasarkan penelitian, kawan sekerja Allah (sunergoi) dalam 1 Korintus 3:4-9 artinya adalah sebagai berikut. Pertama, menjadi kawan sekerja Allah menolong kita terus memperbaharui diri dari manusia lama menjadi manusia baru. Seperti yang dikatakan Coniaris

\footnotetext{
${ }^{4}$ Mencapai theosis adalah mengerjakan keselamatan itu sampai kita dibangkitkan dengan mendapat tubuh kebangkitan yang mulia dan menyatu dengan roh yang telah dewasa menyerupai Kristus.

5 Agung Gunawan, "Pemuridan dan Kedewasaan Rohani," Jurnal Teologi Aletheia 19, no. 12 (Maret 2017): 6.
} 
bahwa bagian Allah adalah untuk memberikan kasih karunia atau rahmat-Nya, sedangkan tugas manusia adalah menerima Anugerah Allah dan tetap menjaganya. ${ }^{6}$ Yang dijaga manusia adalah pakaian baru yang Tuhan Yesus kenakan ke dalam seluruh aspek kehidupan manusia. Pengikut Kristus harus semakin menjadi manusia baru, tak terkecuali kehidupan seorang pelayan Tuhan. Namun, hal menarik yang penulis temukan yaitu bahwa pelayanan adalah untuk mengerjakan keselamatan, artinya saat melayani, pelayanan itu harus membuat seorang pelayan Tuhan semakin kudus, semakin berkorban, semakin rendah hati, semakin serupa dengan Kristus. Bukan sebaliknya, ketika seseorang diijinkan melayani Tuhan tetapi kehidupan kerohaniannya hancur, menyombongkan diri, korupsi persembahan, tidak peduli jemaat. Ada orang yang pelayanannya bagus tetapi kehidupan kerohaniannya ambur adur. Mengapa? Karena dia sedang tidak mengerjakan keselamatannya. Jadi, sinergi dalam pelayanan menolong seorang pelayan Tuhan semakin menguduskan diri dan memperbaiki kehidupan sosialnya bersama dengan sesama pelayan Tuhan lainnya.

Kedua, orang yang tidak menyia-nyiakan kasih karunia Allah terus melawan dosa dan meninggalkan sifat manusiawi seperti perselisihan, kesombongan, iri hati dan mementingkan diri sendiri. Penafsiran secara literal kata esmen dalam ayat 9 menunjukkan Paulus dan Apolos sedang terbeban dengan masalah perpecahan yang dialami oleh jemaat. Penulis berargumen bahwa para pelayan Tuhan saat ini perlu belajar dari cara pelayanan Paulus dan Apolos yaitu memiliki hati yang terus memikirkan jemaat dan sesama pelayan Tuhan bagaimana caranya tetap menjaga keutuhan dan kekompakkan serta persatuan. Cornelius menyatakan bahwa pertobatan jiwa dan kekuatan ilahi nyata terbuka dalam diri pelayan. Penting bagi seorang pelayan untuk sungguh-sungguh bersinergi dengan Allah sebab ia tidak dapat berbuat sesuatu tanpa kasih karunia dari Allah seperti Paulus dan Apolos (1 Korintus 3:9).

Ketiga, orang yang melakukan latihan rohani seperti doa tanpa henti, berjaga-jaga dari pikiran jahat, ${ }^{7}$ berpuasa menahan nafsu makan berlebih dan melakukan kasih. Latihan rohani ini adalah cara bersinergi yang ditawarkan oleh philokalia. Doa tanpa henti isi doanya adalah “Tuhan Yesus Kristus, Anak Allah, kasihanilah aku orang berdosa ini, Amin (Lukas 17: 13; 18:38, Markus 10:47, Matius 20:31; Lukas 18:11-14).

Anugerah Allah yang maha kasih adalah sumber sinergi utama yang Allah tawarkan kepada manusia. Menjadi kawan sekerja artinya Allah memanggil manusia menjadi sahabat (Lukas 12:4) dan rekan sekerja-Nya (1 Korintus 3:9) dalam dunia ini. Mengapa? Karena

\footnotetext{
${ }^{6}$ Anthony M. Coniaris, Philokalia: The Bible of Orthodox Spirituality (Minneapolis: Light \& Life Publishing Company, 1998), 232.

${ }^{7}$ Hendi \& Tiopan Aruan, "Konsep Manusia Baru di Dalam Kristus Berdasarkan Surat Efesus 4:17-32," Evangelikal: Jurnal Teologi Injili dan Pembinaan Warga Jemaat 4, No. 1 ( Januari 2020): 122.
} 
dengan bersinergi atau terus bersahabat dengan Allah menolong manusia melawan godaan nafsu dunia. Melawan godaan nafsu dunia artinya melawan dosa. Yang menarik, Hendi mengatakan bahwa melawan dosa terus diperjuangkan karena Allah akan membuat hati manusia semakin bersinar walaupun masih bisa berdosa. ${ }^{8}$ Seperti yang dikatakan Fr. Stanley Harakas bahwa sinergi dengan anugerah Allah adalah seperti alat pertama dan utama untuk bisa melawan dosa dan kejahatan sebelum seseorang berjuang sendiri melawan godaan dosa. ${ }^{9}$

Menjadi kawan sekerja Allah artinya manusia yang dengan sukarelanya dan kasihnya yang penuh mau menaklukkan kehendak bebas supaya sesuai dengan kehendak Allah. ${ }^{10}$ Roh Kudus yang telah memperbarui nous $^{11}$ kita, tidak tinggal diam melainkan Dia sibuk bersinergi dengan roh kita dalam doa dan berjaga-jaga. ${ }^{12}$ Manusia perlu datang kepada Allah dengan penuh cinta atau keinginan bebasnya atau tanpa paksaan. ${ }^{13}$ Cinta sepenuhnya kepada Allah adalah batu fondasi yang dalam dan meneguhkan hati untuk mau berdarah-darah menyampaikan cinta Tuhan Yesus Kristus yang begitu lebar, panjang dan tinggi dan dalam kepada umat manusia serta mengajak mereka untuk bersama-sama memahaminya (Efesus 3:18). Memberi cinta yang penuh dan kehendak bebas kepada Allah mengingatkan manusia untuk hidup kudus di hadapan Allah serta mengenal isi hati-Nya Allah, yaitu mengabarkan berita baik kepada seluruh bangsa (Matius 28:18-20; Yohanes 6:40). Mengenal isi hati-Nya Allah artinya kita sedang satu visi dengan Allah.

Pelayan Tuhan harus memberi cinta yang penuh kepada Tuhan, orang percaya idealnya perlu dibimbing dan dipengaruhi oleh cinta Tuhan yang penuh. Tujuannya supaya komunitas gereja mengalami keindahan dalam berkomunitas. Jadi, orang percaya yang tidak hidup sepenuhnya dalam cinta Tuhan yang sejati akan sulit memahami orang yang berbeda pandangan dengan dirinya, tetapi ia akan lebih cenderung iri hati, iri hati menghasilkan perselisihan, dan perselisihan menghasilkan perpecahan.

Kawan sekerja Allah juga disebut sebagai para pemimpin gereja atau umat Tuhan. Penulis menambahkan bahwa seorang pelayan yang bersinergi adalah seperti dokter yang sedang menangani pasien kritis dengan cekatan supaya nyawa pasien segera terselamatkan. Pelayan punya tanggung jawab apabila dalam jemaat terdapat masalah. Jemaat Tuhan bisa menjadi kawan sekerja Allah. Jemaat Tuhan yang mendapat identitas sebagai kawan sekerja Allah mengingatkan jemaat: Pertama, untuk terus berjuang melawan keinginan berdosa

\footnotetext{
${ }^{8}$ Hendi, "Pertobatan di dalam Philokalia: Artikel Ulasan," Dunamis: Jurnal Teologi dan Pendidikan Kristiani 3, no. 1 (Oktober 2018): 60.

${ }^{9}$ Harakas Stanley, Introducing the Orthodox Church: Its Faith and Life (Minneapolis: Light and Life Publishing Company, 1993), 133.

${ }^{10}$ Hendi, Formasi Rohani, 74.

${ }^{11}$ Nous adalah inti dari roh yang ada dalam jiwa manusia.

${ }^{12}$ Hendi, Inspirasi Kalbu 2 (Yogyakarta: LeutikaPrio, 2018 ), 58.

${ }^{13}$ Anthony M. Coniaris, Philokalia: The Bible of Orthodox Sprituality (Minneapolis: Light and Life Publishing Company, 1998), 220.
} 
bersama dengan penyertaan Roh Kudus. Kedua, supaya persatuan dan keutuhan tetap terjaga di antara jemaat. Ketiga, supaya jemaat mencapai persatuan dengan Allah.

Kehidupan yang bersinergi adalah kehidupan orang percaya melawan godaan iblis (Efesus 6:12). Caranya adalah bersinergi dengan Roh Kudus dalam doa dan air mata pertobatan yang meratapi dosa serta mengingat api keadilan yang menghanguskan dosa. ${ }^{14}$ Mengapa Roh Kudus? Karena Roh Kuduslah satu-satunya pribadi yang akan membersihkan hati yang telah kotor oleh dosa. Selain itu, Ia juga yang menerangi akal budi kita. Menurut penulis, menjadi kawan sekerja Allah artinya memiliki kehidupan yang terus melawan dosa dengan doa dan mengingat api penghakiman yang akan datang sehingga pelayan Tuhan dan jemaat bisa meninggalkan dosa kesombongan, perselisihan, mementingkan diri sendiri, dan iri hati. Dosa-dosa tersebutlah yang menyebabkan runtuhnya persatuan dengan Allah, dengan sesama pelayan Tuhan dan juga dengan sesama jemaat.

Akan tetapi, hal ini terjadi hanya bagi rekan Allah yang bersungguh-sungguh bersinergi dan terus semangat bekerja di kerajaan Allah yang ada dalam dunia ini. Wesley menuliskan bahwa sinergi ilahi artinya Allah yang sedang bekerja sama dengan para rasul-Nya yang sungguh-sungguh bekerja dalam kerajaan-Nya. ${ }^{15}$ Tidak hanya pelayan Tuhan yang bisa tertolong lepas dari dosa, tetapi setiap orang yang ingin bekerjasama dengan Allah, ia pun pasti lepas dari jerat dosa. Inilah hal pertama, yang menyebabkan menjadi kawan sekerja Allah atau sinergi penting untuk dilakukan karena iblis tidak pernah berhenti, mencari cela, menggoda manusia melakukan dosa yang akhirnya membawa manusia berpisah dari Allah.

Ketika manusia dan Allah bekerja sama, maka pada saat yang sama, manusia mengasihi Allah yang telah menjadi manusia dan Allah terus mengasihi manusia, menolong manusia dalam proses perjalanan hidupnya, perlahan-lahan menuju penyatuan dengan Allah, serta terus berproses mencapai keserupaan dengan Allah. Hendi dan Geralda mengajak orang percaya untuk mendorong diri melakukan latihan rohani meskipun dapat membuat jiwa merasakan kelelahan. ${ }^{16}$ Karena untuk itulah Yesus akan memanggil kita yang berbeban berat kemudian memberikan kelegaan (Matius 11:28-30). Sesungguhnya, yang diterima manusia adalah kasih karunia Allah untuk memperoleh kehidupan yang kekal (Yohanes 15:1-8; 2 Korintus 6:1). Prinsipnya adalah tidak ada pikiran Kristus, tidak ada perasaan Kristus dan tindakan Kristus tanpa rahmat dari Allah.

Keinginan bebas manusia menunjukkan bahwa manusia adalah ciptaan Allah yang istimewa. Mengapa? Karena manusia segambar dengan Allah yang di dalam dirinya ada sifat-

\footnotetext{
${ }^{14}$ Hendi, "Pertobatan di dalam Philokalia," 59-67.

15 J. Wesley Brill, Tafsiran Surat Korintus Pertama (Bandung: Yayasan Kalam Hidup, 1998), 80-81.

${ }^{16}$ Hendi \& Geralda Aprillia Salindeho, "Hesychia Menurut Bapa-bapa Padang Gurun dan Delapan
} Kebajikan Jiwa,” Jurnal Teologi “Cultivation” 4, No. 2, (Desember 2020): 116.111-131. 
sifat Allah, yaitu kasih, kesucian, kehendak bebas, kreativitas, dan lain sebagainya. ${ }^{17}$ Pelayan tidak hanya cukup untuk bersinergi dengan Allah, namun juga memerlukan kawan sekerja Allah. Penulis menjelaskan sub-sub berikut ini:

Sinergi bersama rekan adalah salah satu batu fondasi dalam pelayanan. Mempunyai rekan yang sehati, sepikir, dan setujuan (Filipi 2:2) dalam pelayanan, memudahkan hamba Tuhan untuk bekerja di kerajaan Tuhan dalam dunia ini. Hal ini membuat kita mengerti mengapa Tuhan Yesus memberi instruksi kepada murid-murid-Nya untuk meminta kepada Allah agar mengirim pekerja-pekerja lain yang bisa menjadi rekan tuaian ladang Allah (Matius 9:37-38; Lukas 10:2).

Memiliki hati yang tergerak menyampaikan kabar baik kepada semua orang adalah hal yang baik bagi seorang pemimpin rohani. Namun hal itu tidak cukup, ia perlu meminta rekan kepada Tuhan serta berusaha mencari. Mengapa? Karena ladang Tuhan yang luas masih banyak yang belum dituai. Jadi, bagi hamba Tuhan yang sudah melayani, kita perlu mendoakan rekan kita agar semua rekan tetap sehati, sepikiran, dan setujuan dalam menikmati panggilan Allah sebagai penjala manusia (Matius 4:9), sedangkan bagi yang masih belum diberi kepercayaan melayani, perlu berdoa agar Tuhan menunjukkan siapa rekan yang akan sama-sama memperjuangkan kabar baik tentang Allah yang maha kasih sampai kepada semua orang yang ada di dunia ini.

Kawan sekerja Allah artinya sekawan sehati dengan sesama pelayan dalam pekerjaan Allah. Dalam ayat 9 dijelaskan bahwa Paulus dan Apolos sedang bekerja dengan Allah untuk mengabarkan injil dalam dunia (Markus 16:20). Caesarius mengatakan bahwa pada saat rekan kerja Allah melihat racun kesombongan merambat dalam hati jemaat, ia dengan tergesa-gesa menghancurkannya dengan obat yaitu kerendahan hati yang sejati. ${ }^{18}$ Inilah tugas rekan-rekan Allah, yaitu membawa umat sungguh-sungguh terhadap kerohaniannya.

Kerja pelayan yang bersinergi adalah melayani jemaat yang sedang bermasalah terhadap Tuhan dan terhadap sesama dengan penuh kerendahan hati. Menjadi pelayan Tuhan merupakan pekerjaan mulia yang tidak diperoleh malaikat, raja, bahkan orang tua yang melahirkan dan membesarkan anaknya. Sesungguhnya merekalah dipercayakan dengan kepedihan kesusahan spiritual dan kelahiran yang datang melalui baptisan. Dengan cara demikian jemaat Tuhan dilahirkan baru, mengenakan Kristus, dan dikuburkan bersama Kristus. ${ }^{19}$ Jemaat diumpamakan seperti ladang dan bangunan. Berikut penjelasannya:

\footnotetext{
${ }^{17}$ Hendi, Formasi Rohani: Fondasi, Purifikasi, Deifikasi (Yogyakarta: LeutikaPrio, 2018), 41.

${ }^{18}$ Caesarius, Commentary I Corinthians 3:9 Catena Bible, http://www.catenabible.com/1cor/3 (diakses 27 Maret 2020).

${ }^{19}$ John Chrysostom, Six Books on the Priesthood, ed. Veronika Riml, von Altrosenburg, terj. Graham Neville (Great Britain: SPCK 1907), 2.
} 
Ladang Allah adalah kiasan untuk jemaat kepunyaan Allah. Seperti yang ditulis oleh nabi Yesaya, dalam nubuatannya bahwa bangsa Israel seperti ladang supaya tanaman yang ditanam memperlihatkan keagungan Allah (Yesaya 61:3), dan juga yang dikatakan Yesus dalam perumpamaan tentang benih yang tumbuh bahwa Allah yang menjaga ladang atau jemaat siang dan malam, karena kerajaan Allah seperti benih yang ditabur di ladang (Markus $4: 26)$.

Hasil dari benih yang sudah ditanam adalah menghasilkan pekerjaan baik dan kebajikan jemaat. ${ }^{20}$ John Chrysostom menulis bahwa jemaat terus menerus melakukan kebiasaan menjadi ladang yang terus dipakai Allah untuk menyatakan kerajaan-Nya. ${ }^{21} \mathrm{Jika}$ jemaat adalah ladang maka mereka tidak bisa dibagi dua tetapi harus dikelilingi pagar yaitu pagar tunggal Firman Allah atau nasihat Allah. Penulis melihat bahwa ladang harus diberi pagar supaya musuh tidak mudah masuk menaburkan benih ilalang (Matius 13:25). Dalam pribadi setiap jemaat ada benih yaitu Firman yang sudah disampaikan oleh pelayan Tuhan sehingga ada kebajikan yang bisa dituai oleh Allah dan dinikmati oleh sesama jemaat. Tanaman yang ada di ladang akan terus berproses dalam berakar, bertumbuh, dan berbuah. Proses ini seperti bangunan yang sedang diperbaiki, berikut penjelasannya:

Bangunan Allah adalah tubuh manusia di mana Roh Kudus berdiam supaya Allah ada di tengah-tengah mereka (I Korintus. 6:19; II Korintus. 6:16). Seperti yang dikatakan Anselmus bahwa Roh Kudus adalah arsitek utama dari pembangunan setiap jiwa jemaat. ${ }^{22}$ Kemudian, apa peranan Sang arsitek jiwa jemaat? Hendi menulis bahwa hanya melalui Roh Kuduslah hidup yang kudus disalurkan kepada setiap jemaat asalkan mereka terus bergaul dengan-Nya dalam jiwa. ${ }^{23}$ Jadi, kesadaran jemaat bahwa mereka adalah bangunan Allah memacu jiwa mereka untuk tidak terpecah-belah sebab arsitek jiwa jemaat hanya ada satu, yaitu Sang Roh Kudus yang selalu menyertai. Jemaat Tuhan yang bertumbuh tidak memikirkan perpecahan tetapi memiliki kerinduan untuk terus berusaha bersatu dan berusaha mempersatukan yang sudah retak.

${ }^{20}$ Cornelius, Commentary I Corinthians 3:9 Catena Bible, http://www.catenabible.com/1 cor/3 (diakses 27 Maret 2020).

${ }^{21}$ John Chysostom, Commentary I Corinthians 3:9 Catena Bible, http://www.catenabible.com/1cor/3 (diakses 27 Maret 2020).

${ }^{22}$ Anselmus, Commentary I Corinthians 3:9 Catena Bible, http://www.catenabible.com/1cor/3 (diakses 27 Maret 2020).

${ }^{23}$ Hendi, "Pertobatan di dalam Philokalia: Artikel Ulasan," Dunamis: Jurnal Teologi dan Pendidikan Kristiani 3, no. 1 (Oktober 2018): 56-57. 


\section{Cara Bersinergi}

\section{Para Pelayan dan Jemaat Saling Bekerjasama dengan Allah}

Pelayanan adalah pekerjaan dari seorang pelayan. Menjadi seorang pelayan Tuhan adalah keputusan yang diambil seseorang berdasarkan kehendak bebas yang dihadiahkan Allah kepada manusia. Seorang pelayan mempunyai ergon atau pekerjaan. Menariknya, Paulus menggunakan kata sinergi (sunergon) ketika merujuk kepada "rekan sekerja". Sinergi berasal dari gabungan sun (bersama) dan ergon (pekerjaan). Sinergi bisa diartikan secara harfiah yaitu pekerjaan yang dilakukan bersama-sama.

Sinergi maknanya adalah anugerah Allah bekerja sama dengan jiwa yang tidak menganggur atau jiwa terus berjaga-jaga, jiwa yang diisi oleh Roh Allah, jiwa terus bekerja dan berusaha. Hendi melihat bahwa Paulus adalah orang yang bersinergi dengan Allah. ${ }^{24}$ Paulus bekerja lebih keras dalam pelayanan karena dia tidak sendirian, ia bekerjasama dengan Allah, dan hanya oleh karena anugerah Allahlah Paulus semakin efektif dalam pelayanan serta menghasilkan buah pelayanan. Tidak menganggur menunjukkan kita sebagai hamba Allah tidak cukup hanya berdiam dalam gereja untuk berdoa tanpa melakukan pekerjaan-pekerjaan dengan usaha yang maksimal.

Di sisi lain, Allah yang telah menjadi manusia yaitu Yesus Kristus melayani manusia, sebab Ia adalah wakil manusia di hadapan Allah, yaitu manusia seperti yang dikehendaki Allah, untuk menjadi manusia yang taat, yang menggenapi seluruh kehendak Ilahi. Yesus adalah Firman Allah, dan ketika Firman Allah menjadi manusia, maka Allah mengalami penderitaan bagi manusia, hanya untuk melepaskan manusia dari dosa. ${ }^{25} \mathrm{Jadi}$, Yesus dalam kemanusiaan-Nya melayani dan juga bekerja sama dengan Allah dalam rencana keselamatan Allah.

Di ayat 5, Paulus dan Apolos menyatakan bahwa mereka adalah pelayan-pelayan Tuhan. Hal ini menunjukkan bahwa ketika mereka melayani jemaat Korintus mereka adalah pelayan Tuhan. Sebagai pelayan Tuhan, yang membagi pekerjaan mereka adalah Tuhan. ${ }^{26}$ Sekalipun mereka adalah pelayan, tetapi mereka adalah pelayan-pelayan atas rahasia Allah (1 Korintus 2:7). Tanggung jawab mereka adalah memberitakan kenyataan-kenyataan yang jelas dan tidak ada cacat tentang kebenaran Kristus yang disalib, mati, dan bangkit (1 Korintus $1: 17 ; 2: 2)$. Allah memberikan tanggung jawab memberitakan injil kepada umat manusia,

\footnotetext{
${ }^{24}$ Hendi, Inspirasi Kalbu 3 (Yogyakarta: LeutikaPrio, 2019), 150-53.

${ }^{25}$ Kalimat ini penulis pinjam dari Daniel Byantoro, "Sabelianisme (Part 2)," Youtube, https://www. youtube.com/watch? $\mathrm{v}=\mathrm{zOUwpE7WldE \& t=591s.}$

${ }^{26}$ Donald Guthrie, Tafsiran Alkitab Masa Kini 3: Matius - Wahyu, terj. A. Simanjuntak (Jakarta: Yayasan Komunikasi Bina Kasih, 1982), 483.
} 
menunjukkan bahwa Allah memilih mereka untuk menjadi rekan-Nya memperlebar kerajaanNya dalam dunia.

Allah bisa memakai siapa saja untuk bekerja dalam kerajaaan-Nya, bahkan Ia selalu bertanya, "Siapakah yang akan Kuutus, dan siapakah yang mau pergi untuk Aku?" (Yesaya 6:8). Hal ini menyadarkan setiap orang bahwa Allah yang pertama menawarkan dan bertanya, “Adakah yang mau bekerja untuk Aku?".

Untuk menjadi rekan Allah atau kawan sekerja Allah (1 Korintus 3:9), pada saat yang sama ia adalah pelayan Allah (1 Korintus 3:6). Sebagai rekan Allah kita menyadari diri sebagai pribadi yang bekerja melawan dosa dalam diri bersama Allah dan sebagai pelayan Allah kita bekerja mewartakan kepada semua bangsa bahwa ada Allah yang ingin menyatu kepada manusia (Wahyu 3:20).

Sesungguhnya identitas sebagai pelayan Tuhan, semua pelayanan yang dilakukan hanya untuk memuliakan Tuhan Allah. Identitas sebagai kawan sekerja Allah menolong kita mengerti bahwa tanpa penyertaan Allah dalam pelayanan maupun dalam berjuang melawan dosa, manusia tidak bisa melakukan apa-apa. Mengenal diri sebagai kawan sekerja Allah (rekan kerja atau sinergi) mengingatkan kita sebagai pelayan Tuhan maupun jemaat tetap menjaga rasa persatuan, persahabatan, serta persaudaraan dalam gereja.

Menjadi rekan sekerja Allah menunjukkan bahwa ia adalah seorang yang sevisi dengan Allah. Menjadi rekan sekerja Allah atau bersinergi artinya mengambil bagian dalam mewartakan kepada semua bangsa tentang Allah yang kita percayai, yang menginginkan jiwa manusia menyatu kepada-Nya. Henry berkata bahwa mereka yang menjadi rekan sekerja Allah adalah mereka yang menawarkan tujuan Allah yang mulia yaitu menyelamatkan jiwa bangsa-bangsa yang sangat berharga. ${ }^{27}$

Setiap rekan memiliki visi yang sama bersama dengan rekan lainnya. Visi seorang rekan sekerja Allah adalah menjadikan semua bangsa murid Tuhan Yesus dan mengajarkan kepada mereka apa yang diperintahkan Tuhan Yesus (Matius 28:18-20). Inilah yang harus dilakukan oleh seorang pelayan Tuhan. Mengerjakan pelayanan adalah mengerjakan tujuan Allah menciptakan manusia yaitu untuk menyatu dengan Dia. Mengerjakan pelayanan ketika kita mengajak teman-teman kita yang Kristen maupun yang bukan Kristen untuk sama-sama ikut Tuhan Yesus Kristus.

Pelayan Tuhan menekankan kepada tanggungjawab seseorang yang bekerja untuk Tuhan. Menjadi rekan melibatkan banyak orang, sedangkan menjadi pelayan lebih kepada satu orang yang berusaha melayani dengan lebih baik dari hari sebelumnya. Akan tetapi, baik

${ }^{27}$ Matthew Henry, "1 Corint https://www.biblestudytools.com/commentariescomplete/1corinthians/3.html (diakses 25 November 2020). 
menjadi seorang rekan yang baik maupun menjadi pelayan yang baik, sama-sama diperankan oleh seorang pribadi yang bersinergi dengan Allah.

Dalam pelayanan Paulus dan Apolos di jemaat Korintus, di tengah-tengah perselisihan yang terjadi di antara jemaat, Paulus menyadarkan mereka bahwa mereka tidak lebih dari pelayan Tuhan (ayat 5). Paulus juga mengatakan bahwa ia dan Apolos adalah sederajat. Sederajat artinya memiliki nilai kehidupan manusia yang sama. Paulus mengatakan bahwa setiap pelayan Tuhan memiliki nilai atau harga yang sama dan tidak ada yang dibeda-bedakan (1 Korintus 3:8).

Mereka bekerja untuk tuan-Nya yaitu Allah. Paulus dan Apolos adalah pekerja di ladang Allah dan tukang bangunan Allah (ayat 9). Ditengah situasi yang menegangkan diantara jemaat, Paulus mengingatkan mereka untuk mengingat Allah (bersinergi dengan Allah). Paulus juga mengingatkan bahwa semua manusia memiliki derajat, nilai, harga, yang sama (1 Korintus 3:8). Manusia memiliki derajat dan nilai karena manusia percaya kepada Allah yang adalah sumber dasar nilai kehidupan dan sumber dasar moral yang kekal. Allah adalah Bapa orang percaya (Matius 23:9).

Paulus penting menyatakan diri mereka sebagai pelayan Tuhan, menunjukkan Paulus dan Apolos adalah teladan bagi jemaat di Korintus tentang kerendahan hati dan kesombongan tidak ada artinya. Menjadi pelayan Tuhan bukan berarti jemaat bersikap sewenang-wenangnya sebab pelayanan yang mendatangkan sinergi dengan Allah. Melalui pelayanan Allah justru memperkuat dan menguatkan pelayan-Nya untuk menjadi saksi. Robert Schnase menjelaskan, “Allah memperkuat Tubuh Kristus (orang percaya) melalui misi dan pelayanan." ${ }^{28}$ Mengapa? Karena melalui pelayanan mereka bisa menjadi saksi Kristus dan kerajaan Allah di bumi semakin diperlebar.

Setiap orang masing-masing mempunyai pelayanan yang berbeda. Setiap orang bisa tetap bersinergi meskipun masing-masing memiliki pelayanan yang berbeda-beda. Mengapa? Dalam bersinergi setiap orang diizinkan untuk melayani sesuai kemampuan yang diberikan Tuhan karena sinergi mengingatkan kita bahwa kita adalah manusia yang rapuh membutuhkan pertolongan. Dengan memakai kemampuan pelayanan yang berbeda-beda, kita diberi kesempatan untuk saling menguatkan serta saling bekerjasama menyatu dengan Allah.

Setiap pelayan memiliki keunggulan masing- masing tetapi setiap keunggulan yang berbeda itu dipakai untuk membangun kerohanian jemaat untuk semakin dekat dengan perkenanan Tuhan. Hamba Tuhan itu, memikirkan cara bagaimana membawa perubahan positif dalam hidup jemaat. Pelayanan yang tidak layak diterima Allah adalah para pelayan yang membanggakan kesuksesannya dalam pelayanannya, Tuhan akan merendahkannya

${ }^{28}$ Robert Schnase, 5 Ciri Jemaat yang Bertumbuh (Malang: Gandum Mas, 2016), 87. 
(Lukas 17:10). Setiap orang perlu melayani Tuhan dengan rendah hati sebab hanya dengan itulah Allah bisa membawa orang itu masuk dalam kemuliaan Allah (Yohanes 13: 13-16).

Menyadari bahwa setiap orang punya pelayanan masing-masing bukanlah hambatan untuk tidak bisa bersinergi dengan sesama pelayan Tuhan. Ada beberapa hal yang perlu dilakukan adalah seperti berikut ini. Pertama, menyadari bahwa setiap orang memiliki keunikan yang berbeda sehingga sifat kesombongan yang ada dalam diri harus dihilangkan. Kedua, sadar bahwa setiap orang tidak bisa hidup sendiri, mereka saling membutuhkan, dan saling melengkapi antara satu dengan yang lain dengan menggunakan keunikannya tersebut. Ketiga, menyadari setiap pelayan Tuhan maupun jemaat menjalankan pelayanannya dengan keunikan yang dimiliki dengan maksimal sesuai dengan kehendak dan perintah Allah. Keempat, memotivasi para pelayan Tuhan dan jemaat untuk tidak berhenti melakukan kebajikan terhadap orang lain. Hasil yang diperoleh setelah menyadari dan melakukan hal-hal di atas adalah sebagai berikut. Pertama, kerjasama (sinergi) terjadi diantara pelayan Tuhan maupun jemaat. Kedua, pelayan Tuhan dan jemaat tidak lagi meremehkan sesamanya.

Pelayanan Paulus adalah penginjilan tetapi pelayanan Apolos adalah berkhotbah. Namun tujuan mereka adalah sama, yaitu membawa orang-orang untuk dekat dengan Tuhan Yesus yang sepenuh-Nya kebenaran dan sepenuh-Nya anugerah, sehingga semua manusia dengan sengaja mengenal dan bergaul dengan Allah yang hidup. Tuhan Yesuslah yang mengasihi manusia, yang mau mati dan bangkit demi orang-orang yang Ia kasihi. Pelayanan masing-masing itu apa? Masing-masing manusia diberikan tanggung jawab oleh Allah dalam pelayanan sesuai dengan panggilan. Seorang pelayan Tuhan adalah orang yang mengenal Tuhan dan kemudian memberikan diri untuk diutus Tuhan bekerja dalam kerajaan Tuhan (Yesaya 6:8). Orang yang memberi diri untuk terlibat dalam pelayanan adalah orang yang memberi seluruh hidupnya sebagai persembahan di hadapan Tuhan. Beberapa contoh pelayanan konkret yang bisa dilakukan di masa kini adalah:

Program setelah sekolah untuk anak-anak bermasalah, program dapur makanan untuk fakir miskin, program pelayanan kepada orang-orang tua yang tinggal di panti jompo, pelayanan tetap kepada orang-orang yang dipenjara, dengan sukarela memberi waktu dan tenaga untuk menerima tamu, mengatur tempat parkir, membantu di dapur, bernyanyi dalam tim paduan suara, melayani dalam kepengurusan, kunjungan ke rumah jemaat dan rumah sakit, mengajar sekolah minggu, menyediakan transportasi untuk kaum muda. ${ }^{29}$

Pelayanan bukan hanya di dalam gereja pada setiap kegiatan ibadah, tetapi pelayanan yang menghasilkan sebagai ibadah sejati adalah mengunjungi anak yatim piatu, janda, orangorang susah dan menjaga diri dengan hati-hati supaya tidak dicemarkan oleh dunia (Yakobus 1:27). Schnase juga menambahkan bahwa orang percaya bisa melakukan pelayanan kepada

${ }^{29}$ Schnase, 5 Ciri Jemaat yang Bertumbuh, 87-88. 
orang-orang non-Kristen. Pelayanan ini sering disebut melakukan misi. ${ }^{30}$ Tujuan melakukan misi adalah untuk mengenalkan pribadi Yesus yang diimani melalui teladan kasih, kemurahan, dan keadilan Kristus. Mengapa kasih? Karena nature manusia pada dasarnya adalah kasih.

Benih kasih dapat ditemukan dalam hati setiap orang. Hal ini terjadi karena manusia diciptakan karena kasih Allah sehingga manusia yang merupakan ciptaan paling sempurna karena segambar dan serupa Allah diciptakan tidak untuk mati melainkan untuk hidup bersama Allah dan saling mengasihi. ${ }^{31}$ Joas Adiprasetya dalam jurnalnya menulis bahwa setiap orang percaya atau gereja diberi kesempatan yang sangat luas untuk bersikap lebih bersahabat dan ramah pada kemajemukan tipe spritualitas, ${ }^{32}$ baik kepada gereja yang berbeda tata cara ibadahnya maupun kepada orang yang berbeda kepercayaan. Hal ini menghasilkan kasih yang kita aktualisasikan tidak hanya melulu kepada kelompok yang sama tetapi kepada siapa pun tanpa membeda-bedakan semua orang.

Sikap yang menolong mengenal dan mengalami Allah adalah seperti mengamalkan kasih, dipenuhi sukacita, damai sejahtera, kesabaran, kemurahan, kebaikan, setia, kelemahlembutan dan penguasaan diri (Galatia 5:22-23). Mengamalkan kasih tanpa menuntut balas menolong para pelayan Tuhan mengerti bahwa pelayanan artinya pengorbanan dan bukan tempat untuk mencari keuntungan semata. ${ }^{33}$ Selain itu, menurut penulis mengamalkan kasih yang tulus akan memotivasi para pelayan Tuhan untuk memberikan yang terbaik dalam pelayanannya.

Dalam sinergi, Allah menghargai kehendak bebas manusia, hanya saja manusia masih tidak bisa berdaya tanpa sinergi Allah. ${ }^{34}$ Apa peranan Allah dalam sinergi? Allah memberikan tugas (ay. 5b), memberi pertumbuhan rohani (ay. 6c), dan memberi upah (ay. 8b) kepada semua umat-Nya baik pelayan maupun jemaat. Allah memberikan tugas pelayanan kepada rekan-Nya untuk merebut orang-orang yang dikuasai iblis dan menjadi milik Allah. Orangorang yang telah menjadi wilayah kekuasaan iblis harus direbut kembali oleh Tuhan melalui pekerjaan pelayan Tuhan untuk kebenaran dan kemuliaan-Nya. ${ }^{35}$ Allah yang bersinergi kepada seseorang merupakan hadiah gratis kepada manusia.

Pertumbuhan rohani harus juga dialami pelayan Tuhan, sehingga energi rohani yang diterima dari Allah menjadi kekuatannya untuk bekerja di ladang misi. Dalam kekristenan

\footnotetext{
${ }^{30}$ Ibid, 89.

${ }^{31}$ Hendi, Formasi Rohani, 9.

32 Joas Adiprasetya, "Dari Tangga ke Taman: Multiplisitas Pertumbuhan Iman dan Implikasinya bagi
} Karya Pedagogis, Pastoral, dan Liturgis Gereja," Dunamis: Jurnal Teologi dan Pendidikan Kristiani 4, no. 2 (April 2020): 142.

${ }^{33}$ David Eko Setiawan dan Anton Ishariyono, "Hakikat Spritualitas Pelayan Kristus dan Implikasinya Bagi Hamba Tuhan Masa Kini," Pengarah: Jurnal Teologi Indonesia 2, no. 2 (Juli 2020): 120.

${ }^{34}$ Coniaris, Philokalia, 224.

${ }^{35}$ H. B. London, Jr. dan Neil B. Wiseman, Pelayan Allah yang Berjiwa Besar: Kiat untuk Bertumbuh Kuat dan Pesat Dimana pun Allah Menempatkan Anda, ed. E. Purba, terj. A. J. Syauta (Jakarta: Immanuel 1994), 34. 
Protestan, tidak asing mendengar kata "sinode". Sangat menarik untuk membahas kata "sinode" pada bagian ini, sebab arti dari sinode berdasarkan asal katanya sinodos, yang terbagi menjadi dua kata Yunani yaitu syn (dengan) dan odos (jalan) yang artinya berjalan di jalan yang sama seperti yang dilakukan para murid dengan Yesus di jalan Emaus (Lukas 24:15).

\section{Hasil Sinergi dalam Pelayanan \\ Persatuan Umat}

Persatuan adalah satu kata yang merupakan impian dari para pemimpin gereja atau pelayan Tuhan. Bukan hanya gereja saja yang menginginkan persatuan, organisasi di mana pun yang ada di dunia ini, setiap orang menginginkan persatuan dan kesatuan. Seorang pelatih bola kaki legendaris tim Alabama bernama Paul berkata, "Di atas kejayaan pribadi yang harus diutamakan lebih dahulu adalah mencapai kejayaan tim karena rasa bersatu di dalam tim bisa menghasilkan seorang pemenang." 36 Seperti yang dikatakan Walz bahwa setiap anggota gereja perlu melihat orang lain sebagaimana mereka melihat diri mereka sendiri. ${ }^{37}$ Mereka perlu menyadari bahwa setiap orang diselamatkan oleh Allah sama seperti dirinya. Kesadaran akan betapa berharganya manusia lain dalam gereja sangat penting untuk persekutuan Kristen yang sesungguhnya. Saat anggota gereja tumbuh dalam iman, mereka diharapkan juga bertumbuh dalam kemampuannya untuk saling menerima sebagai bagian dari kesatuan gereja Tuhan. Komunikasi yang baik merupakan alat untuk berhubungan antar umat. ${ }^{38}$ Jadi, persatuan dan kesatuan terjadi jika tidak ada keegoisan dari setiap anggota gereja tetapi saling mengutamakan antara satu dengan yang lainnya.

Menyatu dengan Allah adalah hasil dari bersinergi dengan Allah. Menyatu dengan Allah artinya manusia tidak hanya sekadar masuk surga dan terbebas dari api neraka, tetapi manusia yang bersinergi dengan Allah mengambil bagian dari kodrat ilahi (2 Petrus 1:4). Penyatuan kepada Allah adalah keuntungan setiap orang percaya sebab ia akan lepas dari kuasa iblis, kuasa dosa, bebas dari kelapukan tubuh, kefanaan hidup dan kematian tetapi akan dimanunggalkan dengan tubuh kebangkitan Kristus dan dengan demikian manunggal dengan hidup ilahi (mencapai theosis). ${ }^{39}$

Alasan lain mengapa harus ada persatuan dalam gereja adalah jemaat mengakui mereka berasal dari roh Allah (ay. 4). Sikap kehidupan yang rohanilah yang harus nyata dalam jemaat seperti kehidupan Allah Tritunggal yang bersatu untuk saling mengasihi meskipun dalam 3 pribadi. Daniel Byantoro menuliskan,

\footnotetext{
${ }^{36}$ John C Maxwell, Beyond Talent, ed. Sari Rachmatika, terj. Andi Wahyu (Surabaya: MIC, 2017), 298.

${ }^{37}$ Walz, Bagaimana Mengelola, 181- 182.

${ }^{38}$ Ibid.

${ }^{39}$ Hendi, Inspirasi Kalbu 1 (Yogyakarta: LeutikaPrio, 2017), 11.
} 
Sejak kekal Sang Bapa, di dalam diri Allah yang esa itu, mengasihi Sang Putra. (Yohanes 17:24), kemudian Sang Putra mengasihi Sang Bapa (Yohanes 14:31). Kita harus ingat bahwa baik kasih Sang Bapa kepada Sang Putra maupun Kasih Sang Putra kepada Sang Bapa dicurahkan oleh Roh Allah atau Roh Kudus (Roma 5:5). Bapa berada dalam Putra dan Putra berada dalam Bapa (1 Yohanes 14:9), juga Roh Kudus berada di dalam Sang Bapa, Ia juga tanpa batas berada di dalam Sang Putra, Sang Putra juga berada di dalam Roh Kudus. Itulah sebabnya Firman Tuhan berkata bahwa tidak ada yang bisa mengenal Kristus adalah sebagai Tuhan tanpa penyertaan dan pekerjaan Roh Kudus (1 Korintus 12:3). ${ }^{40}$

Jadi, persatuan gereja harus terus diproklamirkan, diperjuangkan oleh anggota gereja dan pelayan Tuhan dengan terus bersinergi kepada Allah sebagai tanggung jawab iman kepada Allah Tritunggal.

\section{Menjadi Manusia Rohani}

Manusia rohani adalah jiwa jemaat yang bertumbuh mengarah kepada Allah (ay. 6) dengan mengikuti pola dan gaya hidup Kristus dalam kehidupan setiap hari (1 Yohanes 2:6) dan merasa bangga karena memiliki Kristus bukan yang lain. Kebebasan sejati umat Tuhan adalah ketika merasa dalam melakukan segala hal ia tidak pernah bisa melakukan dengan sendiri tanpa penyertaan dari Roh Kudus. Untuk mengatasi rintangan dan tantangan, Roh Allah telah ada dalam diri seperti udara di bawah sayap burung yang membuatnya semakin terangkat ke atas melewati gunung dan lembah. ${ }^{41}$ Iman yang terencana adalah pertumbuhan iman jemaat dalam wujud kasih, dalam hal ini Allah bekerja untuk membentuk jemaat menjadi murid Kristus.

Jemaat yang bersinergi dengan Allah akan berkata, bertindak, berpikir hanya dengan tetap memandang kepada Kristus saja. Orang percaya berdoa dan memandang kepada Allah sebagai pemilik kehidupan. ${ }^{42}$ Bukan memandang kepada keinginan daging. Menjadi manusia rohani adalah melakukan segala hal dengan pikiran Allah. Pola pikir Kristus ada jika seseorang berjaga-jaga atas godaan iblis dan selalu berdoa. ${ }^{43}$ Apabila hal ini dilakukan dengan terus mengingat Allah dalam doa maka kita tidak mudah jatuh dalam dosa tetapi mengarahkan umat semakin manunggal dengan Allah (theosis).

\section{KESIMPULAN}

Berdasarkan apa yang telah penulis jabarkan di atas maka dapat disimpulkan bahwa perpecahan dalam gereja terjadi jika jemaat dan pelayan Tuhan tidak menyadari apa peranannya dalam gereja yaitu bersinergi yang tidak ada henti. Persatuan dalam gereja pada

${ }^{40}$ Daniel B. Byantoro, Aku Percaya: Penjelasan Pengakuan Iman Nikea (Surakarta: Gereja Ortodo Indonesia, 2016), 27.

${ }^{41}$ Coniaris, Philokalia, 226.

124.

${ }^{42}$ Hendi \& Tiopan Aruan, "Konsep Manusia Baru Di Dalam Kristus Berdasarkan Surat Efesus 4:17-32"

${ }^{43}$ Coniaris, Philokalia, 226. 
masa kini terjadi jika umat dan pelayan Tuhan terus bersinergi atau bekerja sama dengan Allah tanpa henti. Persatuan gereja tidak hanya berhenti pada gereja yang ada di dunia tetapi akan terus berlangsung sampai kepada gereja yang AM yaitu gereja kekal. Gereja yang kekal adalah penyatuan Allah dengan umat-Nya untuk selama- lamanya dalam kerajaan Surga. Jemaat dan para pelayan Tuhan harus melatih terus sinergi dengan Allah dengan melakukan disiplin rohani seperti doa tanpa henti sebagai persekutuan dengan Allah yang terus berlanjut, mempratekkan kasih yang tulus, berpuasa, membantah perbuatan dosa, berjaga- jaga, serta membaca Firman Tuhan setiap hari.

\section{REKOMENDASI}

Artikel ini mengajak pelayan Tuhan yang terus bersinergi dengan melakukan kesepakatan sebelum melakukan program pelayanan, memiliki sikap terbuka, terus memperbaiki pelayanan dengan maksimal. Para hamba Tuhan yang menangani jemaat yang sedang berkonflik, perlu menjadi penengah diantara jemaat, mengingatkan mereka untuk kembali bersinergi dengan Allah dengan doa yang tidak putus disertai dengan melakukan perbuatan- perbuatan yang benar kepada Allah dan sesama. Ada beberapa diskusi terkait yang layak mendapat perhatian dalam studi lanjut. Pertama, konsep sinergi antara para pelayan Tuhan dan jemaat. Kedua, konsep sinergi pelayanan kedokteran modern masa kini dengan Allah, yang berusaha menyelamatkan manusia prematur dari kematian dalam pemikiran Yufal Noah Harari.

\section{DAFTAR PUSTAKA}

Adiprasetya, Joas. "Dari Tangga ke Taman: Multiplisitas Pertumbuhan Iman dan Implikasinya bagi Karya Pedagogis, Pastoral, dan Liturgis Gereja." Dunamis: Jurnal Teologi dan Pendidikan Kristiani 4, no. 2 (April 2020): 127-142.

Anselmus. Commentary I Corinthians 3:9. Catena Bible. http://www.catenabible.com/1cor/3 (diakses 27 Maret 2020).

Brill, J. Wesley. Tafsiran Surat Korintus Pertama. Bandung: Yayasan Kalam Hidup, 1998. Byantoro, Daniel. Aku Percaya: Penjelasan Pengakuan Iman Nikea. Surakarta: Gereja Orthodox Indonesia, 2016.

Caesarius. Commentary I Corinthians 3:9. Catena Bible. http://www.catenabible.com/1cor/3 (diakses 27 Maret 2020).

Chrysostom, John. Commentary I Corinthians 3:9. Catena Bible. http:www.catenabible.com/1 cor/3 (diakses 27 Maret 2020).

- Six Books on the Priesthood. Diedit oleh Veronika Riml dan Von Altrosenburg. Diterjemahkan oleh Graham Neville. Great Britain: SPCK, 1907.

Coniaris, Anthony M. Philokalia: The Bible of Orthodox Spirituality. Minneapolis: Light \& Life Publishing Company, 1998.

Cornelius. Commentary I Corinthians 3:9. Catena Bible. http://www.catenabible.com/1 cor/3 (diakses 27 Maret 2020). 
Gordon, Jon. The Seed: Menemukan Panggilan dan Kebahagiaan dalam Hidup dan Pekerjaan. Diedit oleh Esther. M Tanuadji. Diterjemahkan oleh Marlene T. Surabaya: MIC 2011.

Gunawan, Agung. "Pemuridan dan Kedewasaan Rohani." Jurnal Teologi Aletheia 19, no. 12 (Maret 2017): 1-17.

Guthrie, Donald. Tafsiran Alkitab Masa Kini 3: Matius - Wahyu. Diterjemahkan oleh A. Simanjuntak. Jakarta: Yayasan Komunikasi Bina Kasih, 1982.

Hendi. "Bagaimana Membaca Alkitab." Sekolah Tinggi Teologi Soteria Purwokerto, 13 November 2017. https://www.sttsoteria.ac.id/2017/11/tiga-level-pembacaanalkitab.html, (diakses 25 November 2020).

_. Formasi Rohani: Fondasi, Purifikasi, Deifikasi. Yogyakarta: LeutikaPrio, 2018. \& Geralda Aprillia Salindeho "Hesychia Menurut Bapa-bapa Padang Gurun dan Delapan Kebajikan Jiwa," Jurnal Teologi “Cultivation” 4, No. 2, (Desember 2020): 111-131.

—. Inspirasi Kalbu 1. Yogyakarta: LeutikaPrio. 2017.

. Inspirasi Kalbu 2. Yogyakarta: LeutikaPrio, 2018.

. "Pertobatan di dalam Philokalia: Artikel Ulasan," Dunamis: Jurnal Teologi dan Pendidikan Kristiani 3, no. 1 (Oktober 2018): 52-73.

\& Tiopan Aruan, "Konsep Manusia Baru Di Dalam Kristus Berdasarkan Surat Efesus 4:17-32" Evangelikal: Jurnal Teologi Injili dan Pembinaan Warga Jemaat 4, No. 1 ( Januari 2020): 113-130.

Henry, Matthew. "1 Corinthians 3, Bible Study Tools", https://www.biblestudytools.com /commentaries/matthew-henry-complete/1-corinthians/3.html (diakses 25 November 2020).

London, Jr., H. B. dan Neil B. Wiseman. Pelayan Allah yang Berjiwa Besar: Kiat untuk Bertumbuh Kuat dan Pesat Dimana pun Allah Menempatkan Anda. Diedit oleh E. Purba. Diterjemahkan oleh A. J. Syauta. Jakarta: Immanuel 1994.

Maxwell, John C. Beyond Talent. Diedit oleh Sari Rachmatika. Diterjemahkan oleh Andi Wahyu. Surabaya: MIC, 2017.

Palamas, Gregory. The Philokalia. Jilid IV. London: Faber and Faber, 1995.

Pentiuc, Eugen J. The Old Testament in Eastern Orthodox Tradition. New York: Oxford University Press, 2014.

Schnase, Robert. 5 Ciri Jemaat yang Bertumbuh. Malang: Gandum Mas, 2016.

Setiawan, David Eko dan Anton Ishariyono. "Hakikat Spritualitas Pelayan Kristus dan Implikasinya Bagi Hamba Tuhan Masa Kini." Pengarah: Jurnal Teologi Indonesia 2, no. 2 (Juli 2020): 116-128.

Stanley, Harakas. Introducing the Orthodox Church: Its Faith and Life. Minneapolis: Light and Life Publishing Company, 1993.

Tanusaputra, Daniel N. "Kerohanian dan Pelayanan Seorang Hamba Tuhan," Veritas: Jurnal Teologi dan Pelayanan 14, no. 2 (Oktober 2013): 253-276.

Walz, Edgar. Bagaimana Mengelola Gereja Anda. Diterjemahkan oleh S. M. Siahaan. Jakarta: BPK Gunung Mulia, 2008. 